\title{
The Stability Marshall of Asphalt Concrete with the Substitution of Gum Rosin on the Asphalt Penetration 60/70 using Fine Aggregate from Sabang
}

\author{
Cut Nawalul Azka ${ }^{*}$, Sofyan M. Saleh ${ }^{2}$, Sugiarto Sugiarto ${ }^{3}$ \\ ${ }^{I}$ Magister Civil Engineering Faculty of Engineering, Syiah Kuala University in Banda Aceh \\ ${ }^{2,3}$ Civil Engineering Faculty of Engineering, Syiah Kuala University in Banda Aceh
}

*Corresponding Author: Cut Nawalul Azka, Magister Civil Engineering Faculty of Engineering, Syiah Kuala University in Banda Aceh

\begin{abstract}
Basically, aggregate is the one of pavement capacity. The determining of fine aggregate Sabang has low quality because the value absorption is $4.45 \%>3 \%$. The purpose of this research is to identify the effect of gum rosin substitution on asphalt penetration 60/70 with fine aggregate sabang for Marshall characteristics. The trial method is Marshall method by using dry process. Based on the research results the value of optimum bitumen is 5.87\%. from the research result it can be concluded that if the greater value of aggregate then the weight from those type of aggregate is smaller so the weight of the type of maximum mixture become small, whereas the smaller value of aggregate porosity then the weight of the type from those aggregate is larger so that the weight of the maximum type mixture became much larger. The percentage aggregate variation (AHS 50\%:AHI 50\%), (AHS 75\%:AHI 25\%), and (AHS 100\%:AHI 0\%). The results showed the value stability is lower, when percentage of fine aggregate sabang more excessively. The best value stability is $50 \%$ of fine aggregate sabang and 50\% and aggregate from Aceh Besar. The utilizing of value percent fine aggregate sabang that excess is poor in quality, because binding strength not efectif. One way anova show the value of density, VIM, VMA, VFA, Stability Flow and Marshall shows is $F$ count is larger than the value $F$ table and the value of sig. smaller than the value of $\alpha$, it's means Ho is rejected and Ha is accepted, meaning is influential.
\end{abstract}

Keywords: Gum Rosin, Asphalt Penetration 60/70, Fine Aggregate Sabang, Asphalt Concrete-Wearing Course

\section{INTRODUCTION}

In the field are found weakness that often happens on asphalt concrete layer as rutting caused by high temperatures, or secretion granular cause bland strength between bitumen and aggregate. Gum rosin is one of alternative to maintain quality on asphalt, because gum rosin have adhesive on material as thickness. So with the addition of gum rosin, in mixed can receiving traffic load as weight and friction vehicle on surface can be increased. (Puja, 2015). Gum rosin is material produced by distillation of the sap from the tree pinus merkusii shaped solid clear yellow to dark yellow. In Indonesia, industry Gondorukem started at $1938 \mathrm{~s}$, with its first factory in the Takengon (Aceh). The addition gum rosin have asphalt elastic likeness of the nature of asphalt, have a power other materials and impermeable, so that expected to be able to improve the nature, and they work as well a mixture of continuous gradation's asphalt that asphalt concrete-wearing course (Susanto, 2015). Fine aggregate Sabang is one of areas that located in province of Aceh. The determining sand hill is still limited for the lining on asphalt layer. In addition, the increased need for ingredients the way could not be balanced with the availability the source ingredients especially of aggregate's demand, so needs of aggregate in strange area with how to bring the aggregate's demand from other areas. of course, needed for a long time and cost a relative highly. To contribute backup of source alternative material in Sabang, then research needs by doing mixing between fine aggregate from Sabang and fine aggregate from Aceh Besar.

The purpose of research is to know the effect of characteristics a mixed asphalt concrete-wearing course, with gum rosin's substitution into the asphalt penetration and variation the mixing fine 
The Stability Marshall of Asphalt Concrete with the Substitution of Gum Rosin on the Asphalt Penetration 60/70 using Fine Aggregate from Sabang

aggregate from Sabang and fine aggregate from Aceh Besar with the determined as material which can get asphalt optimum performance.

The benefits is to provide the solution and information about ingredients that can be used for a mixture of asphalt concrete with gum rosin's substitution and fine aggregate from Sabang. It expected produce a good strength analysis in mixture of asphalt concrete and cause aggregate will agglutinate.

\section{LITERATURE}

Asphalt concrete-wearing course is type of layers on surface in pavement which directly in vehicle tires so, this layer was designed to endure for climate change, slide force, pressure wheels vehicle tires, and provide a watertight for layer underneath. Selection of material is very important to be determined because in general $\mathrm{AC}-\mathrm{WC}$ mixed performance based on type, quality, and aggregate of material gradation that effect the mixture (Manoppo, 2015). The asphalt ideal is to improve or increase of characteristics a mixture on asphalt and ease a work, asphalt have characteristics as follows: (a) low stiffness or relatively high viscosity, it does not require high temperatures for asphalt pumping, mixing and compacting, (b) high stiffness at high temperatures for asphalt pumping, mixing, and compaction, (c) low stiffness at low temperature (rainy season) to avoid by grooves and syringes, (d) viscosity for high aggregate to avoid stripping. Specification properties of asphalt concrete layers (AC) and (AC-Mod) which can be seen in Table 1 and 2 below:

Table1. Specification Properties of Asphalt Concrete Layers (AC)

\begin{tabular}{|l|l|l|}
\hline Properties of the mixture (AC) & Min & Max \\
\hline Density (gr/cm3) & 2 & - \\
\hline VIM (\%) & 3,0 & 5,0 \\
\hline VMA (\%) & 15 & - \\
\hline VFA (\%) & 65 & - \\
\hline Marshall stability (kg) & 800 & - \\
\hline Flow (mm) & 2 & 4 \\
\hline Marshall Quotient (kg/mm) & 250 & - \\
\hline Marshall stability residu (\%) & 90 & - \\
\hline
\end{tabular}

Source: Bina Marga (2014)

Table2. Provisions Properties of Modified Asphalt Concrete Layers (AC-Mod)

\begin{tabular}{|l|l|l|}
\hline Properties of the mixture (AC-Mod) & Min. & Maks. \\
\hline Density (gr/cm3) & 2 & - \\
\hline VIM (\%) & 3,0 & 5,0 \\
\hline VMA (\%) & 15 & - \\
\hline VFA (\%) & 65 & - \\
\hline Marshall stability (kg) & 1000 & - \\
\hline Flow (mm) & 2 & 4 \\
\hline Marshall Quotient (kg/mm) & 300 & - \\
\hline Marshall stability residu (\%) & 90 & - \\
\hline
\end{tabular}

Source: Bina Marga (2014)

\subsection{Asphalt Elastomeric Polymer Modification}

Polymer modified as asphalt is one types asphalt with addition of polymer to gain the better pavement properties is to reduce deformation on pavement, increases resistance to cracking and stickiness on aggregate (Prastanto, 2015). A mount of polymer added to solid-asphalt, must be determined based on laboratory testing, because the addition of added materials to a certain extent can improve the nature of the asphalt archeology like as; The penetration, viscosity, softening point, and elasticity of asphalt. (Yuniarti, 2015).

\subsection{Gum Rosin}

Gum rosin is a term used as a general designation for a product of processing the sap from the tree pinus merkusii. Gum rosin is a solid material and flammable if thawed. This material is a material that very quickly absorbs heat or fire. 
The Stability Marshall of Asphalt Concrete with the Substitution of Gum Rosin on the Asphalt Penetration 60/70 using Fine Aggregate from Sabang

\subsection{Aggregate Gradation}

Aggregate gradation is distribution of particles aggregate based on the size that forms a bond, thus affecting the stability of pavement (Supriyono, 2017). The details of aggregate gradation for ACWC mixture according to the technical specification of Bina Marga (2014) which can be seen in Table 3 below:

Table3. Specifications of Aggregate Gradation

\begin{tabular}{|c|c|c|}
\hline \multicolumn{2}{|c|}{ Mesh } & Laston (AC-WC) \\
\cline { 3 - 3 } & \% Weight \\
\hline Filter & Size $(\mathrm{mm})$ & Specification \\
\hline $3 /{ }^{\prime \prime}$ & 19,0 & 100 \\
\hline $1 / 2$ & 12,5 & $90-100$ \\
\hline $3 / 8$ & 9,5 & $77-90$ \\
\hline No. 4 & 4,75 & $53-69$ \\
\hline No.8 & 2,36 & $33-53$ \\
\hline No. 16 & 1,18 & $21-40$ \\
\hline No. 30 & 0,60 & $14-30$ \\
\hline No. 50 & 0,30 & $9-22$ \\
\hline No. 150 & 0.15 & $6-15$ \\
\hline No. 200 & 0,075 & $4-9$ \\
\hline Filler & 0 & 0 \\
\hline
\end{tabular}

Source: Bina Marga (2014)

\section{THE METHOD RESEARCH}

The first step in this research is physical properties examination of aggregate and asphalt. After all the results from an examination of material physical properties in accordance with the specification, then make specimens planning and Marshall testing.

\subsection{The Technique of Mixing Asphalt}

The way to increase the asphalt softening point by adding gum rosin. Adding gum rosin into the asphalt increase the asphalt softening point that also dincrese value of penetration. So, it's not affected by the difference in temperature, increase the value of stability and Marshall Quotient. The technique of mixing using dry process, mean is which gum rosin inserted into the aggregate heated at a mixed temperature and then added hot asphalt.

\subsection{Preparation of Test Specimens}

The specimens of AC-WC mixture in this research were made consisting of four groups namely:

1. Specimens with variations of asphalt content for determining optimum asphalt content.

2. Specimens with $4 \%$ gum rosin on $\mathrm{KAO}$ and $\pm 0.5 \% \mathrm{KAO}$.

3. Specimens with $4 \%$ gum rosin and using fine aggregate sabang which result Marshall Characteristic.

\subsection{Method of Data Analysis}

Regression analysis is used to analyze the relationship between the variation of value asphalt on gum rosin into asphalt penetration and combination of aggregate variation with Marshall Parameters. In this research will be obtained several variables are :(a) Dependent is percentage of asphalt, percentage gum rosin, fine aggregate Sabang (b) Independent is stability, Flow, Marshall.

\subsection{One Way - Anova Test}

The Anova in order to purpose identify or not the effect substitution gum rosin on asphalt penetraton. $60 / 70$ and using of combination fine aggregate material Sabang which Marshall parameters, to facilitate calculation using Microsoft Excel

\section{RESULT AND DISCUSSION}

\subsection{Results of Aggregate's Properties}

Results of aggregate's properties can be seen in Table 4. From the results of research, aggregate's properties used has qualify, except the value of flakiness index and elongation index which were 
The Stability Marshall of Asphalt Concrete with the Substitution of Gum Rosin on the Asphalt Penetration 60/70 using Fine Aggregate from Sabang

above $10 \%$, but in the specifications about the coarse aggregate there were conditions that stated when there was a discrepancy, the value can be tolerated, when aggregate specification meet all other provisions, especially when the result of impact and abrasion testing with Los Angeles machine are qualified. The results of the examination the physical properties of asphalt are presented in Table 4.

Table4. Results Properties Test Coarse Aggregate and Fine Aggregate

\begin{tabular}{|c|c|c|c|c|}
\hline Type of Testing & Standard & Value & Unit & Result \\
\hline Bulk Density & SNI 1969-2008 & Min 2,5 & - & 2,807 \\
\hline Absorption & SNI1969-2008 & Maks. 3\% & $\%$ & 0,495 \\
\hline Weight of water & AASHTO T-19-74 & Min $1 \%$ & $\mathrm{Kg} / \mathrm{dm}$ & 1,609 \\
\hline Flakiness Index & ASTM D-4791 & Maks. $10 \%$ & $\%$ & 17.18 \\
\hline Elongation index & ASTM D-4791 & Maks. $10 \%$ & $\%$ & 15.80 \\
\hline Impact & SNI 03-4426-1997 & Maks 30\% & $\%$ & 6,49 \\
\hline Wear & SNI 2417-2008 & Maks. $40 \%$ & $\%$ & 21,52 \\
\hline \multicolumn{5}{|c|}{ Fine Aggragate (Aceh Besar) } \\
\hline Bulk Density & SNI1970-2008 & Min. 2,5 & - & 2,80 \\
\hline Absoption & SNI 1970-2008 & Maks. 3\% & $\%$ & 0,70 \\
\hline \multicolumn{5}{|c|}{ Fine Aggragate (Sabang) } \\
\hline Bulk Density & SNI1970-2008 & Min. 2,5 & & 2,50 \\
\hline Absoption & SNI 1970-2008 & Maks. $3 \%$ & $\%$ & 4,45 \\
\hline
\end{tabular}

\subsection{Results of Asphalt Penetration 60/70}

The properties test of asphalt AC 60/70 produced by PT. Pertamina. Table 5 presents the result of properties test asphalt AC 60/70

Table5. Result Properties Test of Asphalt AC 60/70

\begin{tabular}{|l|c|c|c|c|c|}
\hline \multirow{2}{*}{ Type of Testing } & \multicolumn{2}{|c|}{ Value of Gum rosin } & \multirow{2}{*}{ Unit } & $\begin{array}{c}\text { Asphalt Penetration } \\
60 / 70\end{array}$ & $\begin{array}{c}\text { Elatomeric Polymer } \\
\text { Asphalt }\end{array}$ \\
\cline { 2 - 3 } & $0 \%$ & $4 \%$ & & $\geq 1,0$ & $\geq 1,0$ \\
\hline Specific Gravity & 1,020 & 1.036 & - & $60-70$ & $60-70$ \\
\hline The Penetration & 64 & 58.33 & $(0,1 \mathrm{~mm})$ & $\geq 100$ & $\geq 100$ \\
\hline Duktility & 130 & 133.67 & $\mathrm{Cm}$ & $\geq 48$ & $\geq 48$ \\
\hline Softening point & 48 & 56 & ${ }^{\circ} \mathrm{C}$ & 28 & 2 \\
\hline
\end{tabular}

\subsection{Results of Aggregate Gradation}

In mixture using by ideal gradation on AC-WC mixed as which obtained in specifications of binamarga 2014. In the research can be seen.

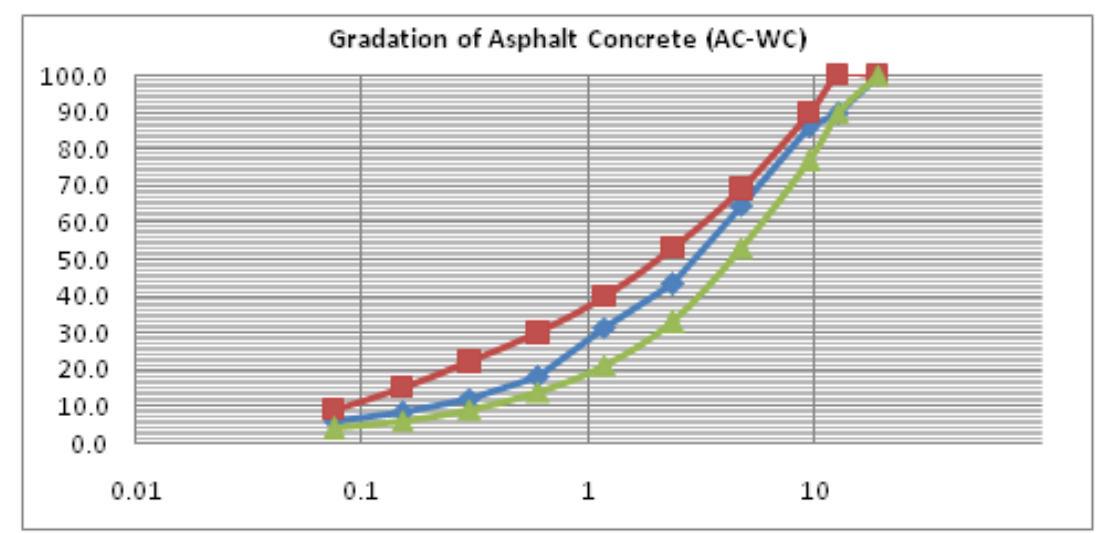

Figure1. Gradation of Asphalt Concrete $(A C-W C)$

\subsection{The Determination of Value Bitumen}

Based on planning gradation which produce the value: $\mathrm{Ca}=56,8 \%, \mathrm{Fa}=37 \%$, Filler $=6.2 \%$ and constants taken was 0.75 . The ideal asphalt content of:

$\mathrm{Pb}=0.035(\% \mathrm{CA})+0,045(\% \mathrm{FA})+0.18(\%$ Filler $)+$ Constanta

$=0.035(56,8 \%)+0,045(37 \%)+0.18(6.2 \%)+0.75$ 
The Stability Marshall of Asphalt Concrete with the Substitution of Gum Rosin on the Asphalt Penetration 60/70 using Fine Aggregate from Sabang

$$
\begin{aligned}
& =1,988+1,665+1,116+0.75 \\
& =5.52
\end{aligned}
$$

Value of the center bitumen mentioned rounded up $0.5 \%$. The variation of asphalt within the range $4.5 \%, 5 \%, 5.5 \%, 6 \%$ and $6.5 \%$ of the total weight of mixture.

\subsection{The Results Asphalt for Value of Optimum Bitumen}

Based on the results, value of the optimum bitumen is $5.87 \%$ that all requirements of Marshall Parameters. The value of optimum bitumen has various into three values of asphalt is 5.38\%; $5.87 \%$; and $6.35 \%$. The three values of asphalt is used for testing the behavior of AC-WC mixture with and without substitution gondorukem. The recapitulation of results of the test of Marshall for the determination of the KAO AC mixture of the toilets are presented in table 6 below:

\begin{tabular}{|c|c|c|c|c|c|c|}
\hline \multirow{2}{*}{$\begin{array}{c}\text { Mixed } \\
\text { Characteristics }\end{array}$} & \multicolumn{5}{|c|}{ The value of asphalt (\%) } & \multirow[t]{2}{*}{ BM specification (2014) } \\
\hline & 4.5 & 5.0 & 5.5 & 6.0 & 6.5 & \\
\hline $\begin{array}{c}\text { Density }(\mathrm{g} / \mathrm{cm} \\
\text { 3) }\end{array}$ & 2.46 & 2.43 & 2.45 & 2.47 & 2.46 & - \\
\hline VIM (\%) & 5.89 & 6.28 & 4.80 & 3.14 & 2,97 & Min. 3 - 5 \\
\hline VMA (\%) & 16,76 & 18,21 & 18.02 & 17,70 & 18,65 & Min 15 \\
\hline VFA (\%) & 64,86 & 65,54 & 73,40 & 82,29 & 84,13 & Min. 65 \\
\hline $\begin{array}{c}\text { The stability } \\
(\mathrm{kg})\end{array}$ & 1731.44 & 1869.80 & 1604.65 & 1269.26 & 1068.93 & Min. 800 \\
\hline Flow $(\mathrm{mm})$ & 3.37 & 3,50 & 3.40 & 3.30 & 2.90 & Min 2-4 \\
\hline MQ (kg/mm) & 518,69 & 571,26 & 494,38 & 400,97 & 368.77 & Min. 250 \\
\hline
\end{tabular}

Table6. Properties of Asphalt Concree without Gum Rosin (60/70)

Table7. Properties of Asphalt Concree With 4\% Gum Rosin

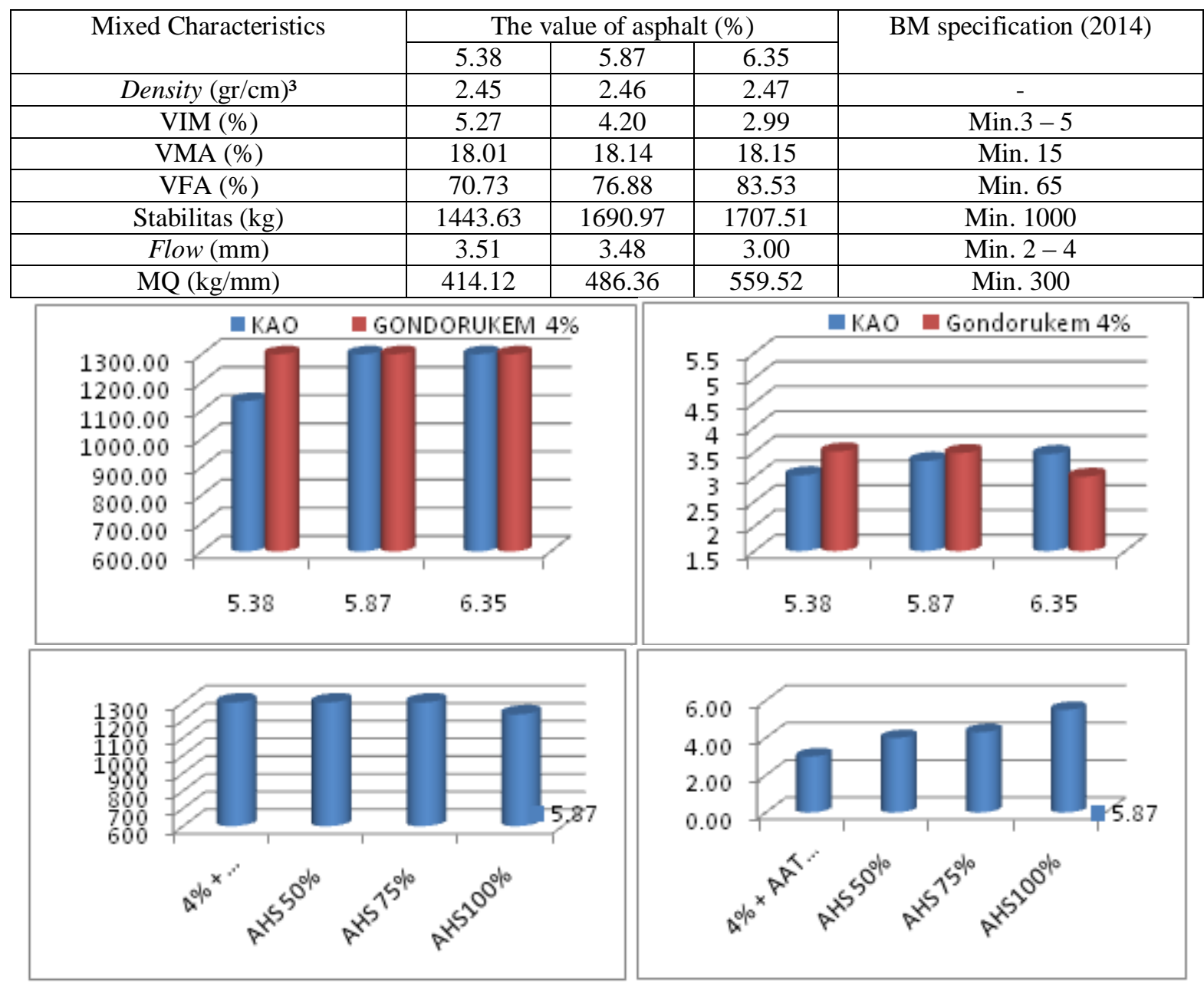

Figure2. The Relationship on Asphalt Optimum between Stability and Flow 
The Stability Marshall of Asphalt Concrete with the Substitution of Gum Rosin on the Asphalt Penetration 60/70 using Fine Aggregate from Sabang

Table8. Properties of Asphalt Concree With 4\% Gum Rosin (60/70) and Fine Aggregate of Sabang

\begin{tabular}{|c|c|c|c|c|}
\hline \multirow{2}{*}{$\begin{array}{c}\text { Mixed } \\
\text { Characteristics }\end{array}$} & \multicolumn{3}{|c|}{ The value of asphalt (5.87\%) } & \multirow{2}{*}{ The specifications BM (2014) } \\
\cline { 2 - 4 } Density (gr/cm) & AHS 50\% & AHS 75\% & AHS 100\% & \\
\hline VIM (\%) & 2.35 & 2.31 & 2.22 & Min. 3 - 5 \\
\hline VMA (\%) & 4.93 & 5.65 & 6.86 & Min. 15 \\
\hline VFA (\%) & 78.27 & 18.76 & 19.46 & Min. 65 \\
\hline The stability (kg) & 1619.23 & 69.93 & 64.81 & Min. 1000 \\
\hline Flow (mm) & 3.99 & 1613.87 & 1232.81 & Min. 2 - 4 \\
\hline MQ (kg/mm) & 413.03 & 4.30 & By 5.50 & Min. 300 \\
\hline
\end{tabular}

In general, stability value in increases with adding of asphalt optimum up to maximum value, however this trend is not seen in gum rosin mixture of substitution, but visible using fine aggregate of Satang. The value of stability for all substitutions requirements that is $800-1000 \mathrm{~kg}$. The addition of gum rosin substitutions into the mixture can provide an indication to improve the durability at high temperature to prevent damage. With the value optimum on asphalt mixture with uses more fine aggregate satang as a replacement has the stability value is lower. The discharge has occurred on the stability value in difference mixed caused a result of the more percentages granular fine aggregate satang who have high absorption.

Table 7, the flow value is inversely with stability. The flow value is influenced by comparison of a mixture on asphalt. The table shows the flow value decreases when the value of bitumen increased. The gum rosin influence on asphalt penetration 60/70, cause the asphalt becomes harder when the mixing with the value of penetration became smaller and softening point will be increased. In Table 8 . It seems with the increasing variation of fine aggregate satang resulted in flow value to be the larger. This logic that it added the value of percentage with fine aggregate satang will the higher the flow value because influence the weight of fine aggregate which light in weight and porosity is larger until the flexibility will be lower.

The amount of value depend by stability which influenced by fictional resistance and interlocking which occurred between aggregate particles and cohesion mixture of rows, as well the flow value influenced by the value of bitumen, material gradation and the amount of impact . Table 8 , The Marshall Quotient value an AC-WC mixture was the requirements of all variation fine aggregate of Satang. The Marshall Quotient value influenced by stability and flow. From the Table 8, The Marshall Quotient value is the lower with increases of aggregate percentage in fine aggregate of Satang. Fine aggregate satang $50 \%$ which has the best value of stability, then aggregate $75 \%$ and $100 \%$. Caused they have low angularitasnya and produce friction between the low aggregate particles so the mixture is obtained more flexible with the low value of stiffness.

\subsection{The Results of ANOVA Analysis with Marshall Parameters}

Variable Analysis (ANOVA) on Stability Marshall and regression analysis can be seen in Table 9:

Table9. Properties of Asphalt Concrete (60/70) With Regression Analysis

\begin{tabular}{|c|c|c|}
\hline Marshall Parameters & Regression equation & R2 \\
\hline Desity $(\mathrm{gr} / \mathrm{cm})^{3}$ & $\mathrm{Y}=0.011 \mathrm{x} 2-0.117 \mathrm{x}+2.75$ & 0.298 \\
\hline VIM (\%) & $\mathrm{Y}=-0.368 \mathrm{x} 2+2.256 \mathrm{x}+3.538$ & 0.877 \\
\hline VMA (\%) & $\mathrm{Y}=-0.325 \mathrm{x} 2+4.230 \mathrm{x}+4.61$ & 0.572 \\
\hline VFA (\%) & $\mathrm{Y}=0.96 \mathrm{x} 2+0.496 \mathrm{x}+41.79$ & 0.933 \\
\hline The stability $(\mathrm{kg})$ & $\mathrm{Y}=-213.6 \mathrm{x} 2+1964 \mathrm{x}-2728$ & 0.979 \\
\hline Flow $(\mathrm{mm})$ & $\mathrm{Y}=-0.302 \mathrm{x} 2+3.103 \mathrm{x}-4.462$ & 0.855 \\
\hline MQ $(\mathrm{kg} / \mathrm{mm})$ & $\mathrm{Y}=-49.44 \mathrm{x} 2+452.5 \mathrm{x}-496.1$ & Nominal \\
\hline
\end{tabular}

ANOVA is a type of regression where independent variables are nominal variables. Nominal variable is one that has two or more levels, but there is no intrinsic ordering for the levels. ANOVA stands for Analysis of Variance. It is used to compare more than two means. As the name suggest, it estimate a variance and based on the variance, it allow us to make a conclusion about the comparison of means. 
The Stability Marshall of Asphalt Concrete with the Substitution of Gum Rosin on the Asphalt Penetration 60/70 using Fine Aggregate from Sabang

It is true that we can also use t-test to compare more than two means. But, t-test will increase the typeI-error when t-test does multiple comparisons on the same data. Depends on the number of independent variable.

Table10. Properties of Asphalt Concree With 4\% Gum Rosin (60/70) With Anova

\begin{tabular}{|c|c|c|c|c|c|}
\hline \multirow{2}{*}{$\begin{array}{c}\text { Mixed } \\
\text { Characteristics }\end{array}$} & \multicolumn{4}{|c|}{ The value of asphalt $5.87 \%$ with fine aggregate variations } & \multirow[t]{2}{*}{ Conclusion } \\
\hline & The value of & The value of & The value & Anova Test & \\
\hline Density & $\begin{aligned} \mathrm{F}_{\text {hitung }} & =46.000 \\
\text { Sig. } & =0,00\end{aligned}$ & $\begin{array}{c}\mathrm{F}_{\text {table }}=4.066 \\
\alpha=0,05\end{array}$ & $\begin{array}{l}\mathrm{df}_{1}=3 \\
\mathrm{df}_{2}=8\end{array}$ & $\begin{array}{l}\text { Ho rejected } \\
\text { Ha accepted }\end{array}$ & Effect \\
\hline VIM & $\mathrm{F}_{\text {hitung }}=6.286$ & $\mathrm{~F}_{\text {table }}=4.066$ & $\mathrm{df}_{1}=2$ & Ho rejected & Effect \\
\hline VMA & $\begin{array}{c}\mathrm{F}_{\text {hitung }}=4.229 \\
\text { Sig. }=0,04\end{array}$ & $\begin{array}{c}\mathrm{F}_{\text {table }}=4.066 \\
\alpha=0,05\end{array}$ & $\begin{array}{l}\mathrm{df}_{1}=3 \\
\mathrm{df}_{2}=8\end{array}$ & $\begin{array}{l}\text { Ho rejected } \\
\text { Ha accepted }\end{array}$ & Effect \\
\hline VFA & $\begin{array}{c}\mathrm{F}_{\text {hitung }}=7.558 \\
\text { Sig. }=0,01\end{array}$ & $\begin{array}{c}F_{\text {table }}=4.066 \\
\alpha=0,05\end{array}$ & $\begin{array}{l}\mathrm{df}_{1}=3 \\
\mathrm{df}_{2}=8\end{array}$ & $\begin{array}{l}\text { Ho rejected } \\
\text { Ha accepted }\end{array}$ & Effect \\
\hline The stability & $\begin{array}{c}\mathrm{F}_{\text {hitung }}=17.030 \\
\text { Sig. }=0,00\end{array}$ & $\begin{array}{c}\mathrm{F}_{\text {table }}=4.066 \\
\alpha=0,05\end{array}$ & $\begin{array}{l}\mathrm{df}_{1}=3 \\
\mathrm{df}_{2}=8\end{array}$ & $\begin{array}{l}\text { Ho rejected } \\
\text { Ha accepted }\end{array}$ & Effect \\
\hline Flow & $\begin{array}{c}\mathrm{F}_{\text {hitung }}=10.298 \\
\text { Sig. }=0,00\end{array}$ & $\begin{array}{c}\mathrm{F}_{\text {table }}=4.066 \\
\alpha=0,05\end{array}$ & $\begin{array}{l}\mathrm{df}_{1}=3 \\
\mathrm{df}_{2}=8\end{array}$ & $\begin{array}{l}\text { Ho rejected } \\
\text { Ha accepted }\end{array}$ & Effect \\
\hline MQ & $\mathrm{F}_{\text {hitung }}=9.444$ & $\mathrm{~F}_{\text {table }}=4.066$ & $\mathrm{df}_{1}=3$ & Ho rejected & Effect \\
\hline
\end{tabular}

Based on the results of Anova analysis, obtained the significance value of the significance for asphalt value and interaction between the asphalt value and concentration of additives to the parameters is $0.00,0.01$, and 0.04 . From the three factors, all significant factors because it has significance value is alpha (0.05) which means $\mathrm{H} 0$ rejected. So, it can be concluded that there is influence of gum rosin and fine aggregate Satang for Marshall Stability.

\section{Conclusion And Suggestions}

\subsection{Conclusion}

1. With the range of value of optimum bitumen which smaller than $1 \%$. So, the mixture will be tested at the beneath range, center range, and on top of range is $5.38 \% ; 5.87 \%$ and $6.35 \%$. The three values of asphalt for the test of characteristics of AC-WC mixture.

2. Variations in the aggregate value influence of $\mathrm{AC}$ WC mixture. In greater who fine aggregate satang used will give a some characteristics of AC-WC mixture as follows: discharge in the stability value of stability. But, increase the flow value, Increase in the VIM and VMA. But decrease in the VFA. The increased significantly on the value mixture will decrease by fine aggregate satang

3. The value of fine aggregate satang which the performance of asphalt mixture optimum concrete is interval (AHS50\%:AHI50\%) for the total weight of aggregate. The determination of tolerance value of fine aggregate satang is done. Based on the evaluation of Marshall for the characteristics is stability, flow, VIM, VMA, VFA, Density, and Marshall Questions.

\subsection{Suggestions}

Based on the research as well the process that has been passed by researchers, proposed some suggestions as follows:

1. From this study, it could be recommended that asphalt concrete mixtures prepared using waste gum rosin as a asphalt substitution and fine aggregate satang as a partial aggregate substitution would be better if it applied in the mixture as a base course.

2. Can be done further research to examine the utilization of fine aggregate satang using the type of asphalt that more varied.

3. This research is expected to be more developed to further research using chemicals

4. Can provide stickiness power asphalt is more powerful for satang fine aggregate in order to be used as much as $100 \%$

5. This research is expected to be developed further to examine more deeply influence of the addition of fine aggregate satang on the impact of the weather.

6. This research is expected to be a reference for the connected especially in the field of pavement 
The Stability Marshall of Asphalt Concrete with the Substitution of Gum Rosin on the Asphalt Penetration 60/70 using Fine Aggregate from Sabang

\section{REFERENCES}

[1] Alamsyah, Ansyori Vacillate, 2017, The Utilization Of Baggase Ash As Filler With Variation Of Asphalt Treatment Base Asphalt Treatd ATB (Base), the Journal of National Seminar on technology and Engineering (Central), Muhammadiyah University, Malang

[2] Arlia, Leni. The Characteristics Of Porous Asphalt Mixture With The Substitution Of Gum Rosin On The Asphalt Penetration 60/70, The Journal of the thesis, Volume X, No. X, June 2017, UNSYIAH, Banda Aceh

[3] Manoppo, M. Elisabeth, L, Jansen F, Encrustation Mountains As Alternative Aggregate On Asphalt Mixture, scientific journals Media Engineering, Sam Ratulangi University, ISSN 2087-9334 (11-25), Vol 2, No 1 March 2012

[4] Prastanto, H. Cifriadi, A. Ramadan, A, 2015, Characteristic and Marshall of Modified Asphalt with Depolymerized Natural Rubber as Additives, Rubber Research Journal January 201533 (1) : 75 - 82, Bogor

[5] Puja, Prime, H. (2015), Asphalt Stiffness Test Using Add Rubber Gum rosin. Journal thesis, AI. Unand library.

[6] Supriyono, Setiadji, H.B. Marpaung A. Indira, 2017, Evluation of Aggregate Gradation on the mixture using the theory of Fractal. Volume 6, Number 2, 2017, page 1 - 11. Major in Civil Engineering Faculty of Engineering, Diponegoro University, Tembalang, Semarang.

[7] Susanto, H, Akmal, M. F, Saputri, M. D, 2015, The Utilization Pine as the modification of asphalt on a mixture of AC-WC, Paper Road Competition National Cbr Unila, National Institute of Technology Bandung

[8] Yuniarti, R, 2015, Modify Asphalt with pine and Fly Ash to produce Bio-Aspal, Journal Science and Technology Environment, Technique Faculty of the University of Mataram, Vol 1 No 2 (2015).

Citation: Cut Nawalul Azka, et.al. "The Stability Marshall of Asphalt Concrete with the Substitution of Gum Rosin on the Asphalt Penetration 60/70 using Fine Aggregate from Sabang”, International Journal of Constructive Research in Civil Engineering, 5(1), pp. 16-23. DOI: http://dx. doi.org/10.20431/24548693.0501003

Copyright: (C) 2019 Authors, This is an open-access article distributed under the terms of the Creative Commons Attribution License, which permits unrestricted use, distribution, and reproduction in any medium, provided the original author and source are credited. 